\title{
A comprehensive evaluation of symptom scores designed to inform the triage and diagnosis of cow's milk protein allergy in children: a systematic review of the research evidence
}

\author{
Georgina Thompson ${ }^{1}$, Zhivko Zhelev ${ }^{1}$, Jaime Peters ${ }^{1}$, Sara Khalid ${ }^{1}$, Simon Briscoe ${ }^{1}$, Liz \\ Shaw $^{1}$, Michael Nunns ${ }^{1}$, Sian Ludman ${ }^{2}$, and Christopher Hyde ${ }^{1}$ \\ ${ }^{1}$ University of Exeter Medical School \\ ${ }^{2}$ Royal Devon and Exeter NHS Foundation Trust
}

August 12, 2020

\begin{abstract}
Background: Cow's milk protein allergy (CMPA) is an immune-mediated allergic response to proteins in milk, a common infant food allergy. The wide range and frequency of CMPA symptoms make diagnosis a challenge, particularly in primary care. Symptom scores may improve a clinician's awareness of symptoms, thus indicating a need for further testing. This systematic review examined the development and evaluation of such symptom scores for use in infants. Methods: Four databases were searched from inception to 3 December 2019, for diagnostic accuracy studies, randomised controlled trials, observational studies, economic evaluations, qualitative studies, and studies reporting on the development of the tools. Experts were consulted for additional studies. Data were not suitable for meta-analysis due to heterogeneity, so were narratively synthesised. Results: We found two symptom scores evaluated in one and fourteen studies, respectively. Estimated sensitivity and specificity ranged from $37-98 \%$ and $38-93 \%$. The evaluations of each tool were at high risk of bias or failed to address issues such as clinical and cost-effectiveness. Conclusions: Estimates of accuracy of symptom scores for CMPA offered so far should be interpreted cautiously. Rigorous research based on well-defined roles for the tools and free of potential conflicts of interest is urgently required.
\end{abstract}

A comprehensive evaluation of symptom scores designed to inform the triage and diagnosis of cow's milk protein allergy in children: a systematic review of the research evidence

Running title: Symptom scores for milk allergy

Georgina Thompson ${ }^{1}$, Zhivko Zhelev ${ }^{1}$, Jaime Peters ${ }^{1}$, Sara Khalid ${ }^{2}$, Simon Briscoe ${ }^{2}$, Liz Shaw ${ }^{2}$, Michael Nunns $^{2}$, Sian Ludman ${ }^{3}$, Christopher Hyde ${ }^{1}$

${ }^{1}$ Exeter Test Group, University of Exeter Medical School, University of Exeter, Exeter, UK

${ }^{2}$ University of Exeter Medical School, University of Exeter, Exeter, UK

${ }^{3}$ Royal Devon and Exeter NHS Foundation Trust, Exeter, UK

\section{Acknowledgements}

We would like to acknowledge the contributions of Professor Stuart Logan at University of Exeter Medical School and Flamingos Allergy Toddler Group in developing this systematic review. 


\begin{abstract}
Background: Cow's milk protein allergy (CMPA) is an immune-mediated allergic response to proteins in milk, a common infant food allergy. The wide range and frequency of CMPA symptoms make diagnosis a challenge, particularly in primary care. Symptom scores may improve a clinician's awareness of symptoms, thus indicating a need for further testing. This systematic review examined the development and evaluation of such symptom scores for use in infants.
\end{abstract}

Methods: Four databases were searched from inception to 3 December 2019, for diagnostic accuracy studies, randomised controlled trials, observational studies, economic evaluations, qualitative studies, and studies reporting on the development of the tools. Experts were consulted for additional studies. Data were not suitable for meta-analysis due to heterogeneity, so were narratively synthesised.

Results: We found two symptom scores evaluated in one and fourteen studies, respectively. Estimated sensitivity and specificity ranged from $37-98 \%$ and $38-93 \%$. The evaluations of each tool were at high risk of bias or failed to address issues such as clinical and cost-effectiveness.

Conclusions: Estimates of accuracy of symptom scores for CMPA offered so far should be interpreted cautiously. Rigorous research based on well-defined roles for the tools and free of potential conflicts of interest is urgently required.

\title{
Key words
}

Cow's milk allergy; Symptom score; Systematic review

\section{Background}

Cow's milk protein allergy (CMPA) is an immune-mediated allergic response to proteins in milk, one of the most common infant food allergies. The reported cumulative incidence by age 2 in the UK is $2.4 \%$ (an estimated 18,100 infants born in 2017). ${ }^{1}$ Depending on the underlying pathophysiology and clinical presentation, CMPA is classified as immunoglobulin E ( $\operatorname{IgE})$ mediated, non-IgE mediated or mixed. IgEmediated reactions typically occur immediately after ingestion whereas non-IgE mediated are delayed, taking up to 48 hours to develop, but still involve the immune system. ${ }^{2}$ In infants, CMPA can present with a wide range of symptoms, from acute reactions, such as pruritus, angioedema and anaphylaxis, to nonacute symptoms, such as faltering growth, and gastro-intestinal and dermatological manifestations. ${ }^{3}$ Seventy percent of cases are classified as non-IgE mediated CMPA, which are most commonly associated with nonacute, generalised symptoms. ${ }^{1}$

The wide range and frequency of these symptoms makes this a diagnostic challenge, particularly in the primary care setting. ${ }^{4}$ Whereas IgE-mediated and mixed reactions may be identified by skin prick testing (SPT), food allergen-specific serum $\operatorname{IgE}$ (sIgE) determination, and oral food challenges (OFC), non- $\operatorname{IgE}-$ mediated reactions are more difficult to identify with currently available techniques. ${ }^{2}$ Furthermore, pooled accuracy of such techniques is modest with sensitivities of $88 \%$ (95 \% CI 76-94), and 87\% (95\% CI 75-94) and specificities of $68 \%$ (95\% CI 56-77), and $48 \%$ (95\% CI 36-59), for SPT and sIgE, respectively. ${ }^{5}$ The double-blind, placebo-controlled food challenge (DBPCFC) is considered the gold standard for diagnosis of food allergy. However, it is difficult to perform, expensive, and may not be readily available in many clinical settings. Moreover, non-IgE-mediated reactions depend on the quantity of exposure and may have a prolonged delay for symptom onset, which may further lead to under diagnosis based on OFC leading to poor nutritional intake, failure to thrive, or worsening eczema. ${ }^{6,7}$ NICE guidelines recommend that where CMPA is suspected, an allergy-focused history should be taken before deciding whether and what further tests to perform. ${ }^{8}$ Despite this, a lack of awareness of the existing guidelines amongst GPs and inconsistency across the guidelines themselves, leads to uncertainty and variation in diagnosis. ${ }^{9-11}$ 
Accurate and timely identification of CMPA will improve outcomes for infants and their families, reduce the need for unnecessary invasive and expensive investigations in symptomatic infants, and reduce the economic burden of management. ${ }^{12}$ Delays in appropriate diagnosis of CMPA reflect both poor awareness of the condition and insufficient capacity in primary care to effectively apply the recommended diagnostic strategy. ${ }^{9}$ Symptom scores, such as the commercially available Cow's Milk-related Symptom Score (CoMiSS ${ }^{\mathrm{TM}}$ ), have been created to be used in the clinical setting for increasing awareness of CMPA in infants. ${ }^{13}$ They are lists of symptoms where the presence of a certain number of symptoms is interpreted as a possible indicator of CMPA. Despite being widely available online, there is limited information on the development, validity and accuracy of symptom scores for CMPA. ${ }^{14}$ Evaluating the quality and performance of these tools will help clinicians to make informed decisions about their use, and their limitations, in the clinical setting, and improve the early stages of the diagnostic process. We have systematically reviewed the research evidence pertaining to the development and evaluation of symptom scores used to raise awareness of CMPA.

\section{Methods}

We followed Cochrane Collaboration recommendations for best practice, ${ }^{15}$ and the review protocol is registered on PROSPERO (registration number CRD42020165606).

\section{Inclusion and exclusion criteria}

We included diagnostic accuracy studies, randomised controlled trials and observational studies, economic evaluations, and qualitative studies, including systematic reviews, reporting on the development and evaluation of symptom score tools for suspected CMPA. Study subjects included infants aged 0-36 months. Case reports, conference abstracts and meeting reports were excluded.

\section{Search strategy}

The search strategy was developed by GT and SB. We searched CENTRAL (via the Cochrane Library), MEDLINE (via Ovid), Embase (via Ovid), and CINAHL (via EBSCO) from inception to 3 December 2019. No language or study type restrictions were applied. Search strategies combined indexing (e.g. MeSH in MEDLINE) and title and abstract keyword terms for 'milk', 'allergy' and 'infant' and 'score' (see Supplementary file 1). We also searched the World Health Organisation International Clinical Trials Registry Platform and conducted forward and backward citation searches on included studies. Forward citation searching was conducted using ResearchGate and backward citation searching was conducted by manually inspecting the reference lists of included studies. Topic experts were contacted to check for additional publications or relevant unpublished data. Search results were exported to and managed using Endnote X8 reference management software.

\section{Study selection}

Two authors (GT, SK) independently reviewed the titles and abstracts, and subsequently the full texts of studies identified from the literature search. Any disagreements were resolved by discussion. Study authors were contacted as needed for clarification.

\section{Data extraction and quality appraisal}

A standardised data extraction form was developed and piloted (GT, ZZ) (see Supplementary file 2). One author (GT) extracted all data, which were then checked by a second (SK). Three authors (GT, ZZ, JP) independently assessed the methodological quality of the included studies and resolved any disagreements through discussion. We used QUADAS-2 for test accuracy studies and PROBAST for studies reporting the development and piloting of the symptom scores. ${ }^{16,17}$ Although these studies did not report development 
or validation of prediction models, we felt that aspects of PROBAST would be useful in appraising their quality. Studies in which a symptom score was used to assess the effectiveness of specialist milk formula were included for completeness, but since they did not report data on the performance of the tool no quality assessment was carried out.

\section{Data analysis, synthesis and reporting}

Summary tables for each evaluation were created. Symptom scores were analysed separately, and comparisons between them were made narratively. Results from test accuracy studies were summarised by the number of false positive, false negative, true positive and true negative results, and sensitivity and specificity estimates. Forest plots were generated for each test pair of sensitivity and specificity across studies using Review Manager 5.4. ${ }^{18}$ Data were not pooled due to the small number of studies reporting both sensitivity and specificity, and extensive heterogeneity amongst included studies.

\section{Results}

\section{Study selection}

1139 studies were identified (excluding duplicates) with 84 eligible for full-text review. Fourteen studies met our inclusion criteria. One further study was identified through citation searches, resulting in a total of 15 included studies in this review. The study selection process is shown in Figure 1.

\section{Included studies}

Two symptom scores were evaluated in the 15 included studies (see Table 1). One test accuracy study from the USA evaluated the CMPA questionnaire. The remaining fourteen studies focused on CoMiSS ${ }^{\mathrm{TM}}$ and were conducted in Belgium $(n=7)$, Italy $(n=2)$, and one in each of Poland, United Kingdom, India, Turkey and China; these consisted of five test accuracy studies, five effectiveness studies using CoMiSS ${ }^{\mathrm{TM}}$ as an outcome measure, and four studies on aspects of the development and piloting of CoMiSS ${ }^{\mathrm{TM}}$. No relevant economic evaluations were identified.

\section{Description of included symptom scores}

\section{CoMiSS $^{\mathrm{TM}}$}

The symptom-based score, now known as the Cow's Milk-related Symptom Score (CoMiSS ${ }^{\mathrm{TM}}$ ), was developed by consensus of 18 experts from 14 different hospital sites in Belgium. ${ }^{13}$ It includes GI symptoms (regurgitation, altered stool composition), skin manifestations (eczema, urticaria), respiratory tract symptoms and general symptoms such as crying time (see Figure 2). The overall score ranges from zero to 33, with each symptom having a maximum score of six, apart from respiratory symptoms, with a maximum score of three. An arbitrary cut-off point of $>12$ was originally selected as the criterion to highlight infants at risk of CMPA who require further testing; a score of which would require the presence of at least two severe symptoms. CoMiSS ${ }^{\mathrm{TM}}$ is made available online through Nestlé Health Science. ${ }^{19}$

\section{CMPA questionnaire}

Gibbons et al. aimed to evaluate a multisystem questionnaire that would help diagnose non-Ig-E-mediated early CMPA and be easy to apply and score in a busy clinical setting. ${ }^{7}$ Symptoms for the questionnaire were selected based on chart reviews of patients diagnosed with CMPA and a literature review of its clinical manifestations in infants. Each symptom scores 1 for a positive response, and 0 for a negative response, and 
an overall score was calculated (see Figure 3). Vomiting was scored based on frequency. ROC analysis was used to determine a cut-off point that results in balanced performance in terms of sensitivity and specificity.

\section{Methodological quality of included studies}

\section{Development and piloting studies}

Risk of bias for the CoMiSS ${ }^{\mathrm{TM}}$ studies was high due to: all studies recruiting infants who were presumed healthy with no confirmatory tests for whether they had CMPA; lack of clarity on who completed the CoMiSS $^{\mathrm{TM}}$ and whether they were blinded to allergy status of the infant; no details provided for infants who scored $>12 .{ }^{20-22}$ Applicability of these studies was also poor; the CoMiSS ${ }^{\mathrm{TM}}$ was performed on healthy infants whose CMPA status was deemed to be negative, but no clear test or criteria for exclusion of those not having CMPA was reported. ${ }^{20-22}$

\section{Diagnostic test accuracy studies}

The quality of included DTA studies is summarised in Figure 4. Methodological quality was poor in the risk of bias domains, where all studies scored high risk in at least two domains. Three studies were at high risk in the patient selection domain; two used a case-control study design, ${ }^{7,8}$ and one study did not use a consecutive or random sampling method, but instead included only infants that scored a CoMiSS ${ }^{\mathrm{TM}}$ of $>12 .{ }^{23} \mathrm{Three}$ studies demonstrated high risk of index test interpretation bias, due to the lack of pre-specified threshold criterion for a positive screen and a lack of blinding to the results of the reference standard. ${ }^{7,23,24}$ All six studies were at high risk of bias in the reference standard domain because the reference standard DBPCFC was not used, while, one study included the index test in the reference standard. ${ }^{25}$ Five studies scored high risk of bias for flow and timing; one left an interval of up to 3 months between applying CoMiSS ${ }^{\mathrm{TM}}$ and conducting $\mathrm{OFC},{ }^{25}$ two excluded eligible infants from the analysis, ${ }^{7,23}$ and two used different reference standards to establish CMPA. ${ }^{8,26}$ Full details on the methodological quality of these studies can be found in Supplementary file 3 .

Overall, most studies scored low concern for applicability. Concern with regards to patient selection was found in two studies; one selected infants with a prior diagnosis of CMPA, ${ }^{8}$ and one failed to provide details regarding the setting from which patients were selected. ${ }^{23}$ Two studies scored high for concerns regarding index test applicability because the index test was performed after an elimination diet rather than at presentation. ${ }^{8,23}$

\section{Funding}

Ten studies acknowledged conflicts of interest with regards to authors' connections to pharmaceutical or milk formula industries, including companies that have been involved in the development of CoMiSS ${ }^{\mathrm{TM}}$. Seven studies received funding from the pharmaceutical or milk formula industry. ${ }^{13,23,24,27-30}$

\section{Main findings}

\section{$\operatorname{CoMiSS}^{\mathrm{TM}}$}

\section{Development and piloting studies}

Four studies reported on the development and/or initial validation of the CoMiSS ${ }^{\mathrm{TM}}$ tool. ${ }^{13,20-22}$ The development study stated that the predictive value of $\mathrm{CoMiSS}^{\mathrm{TM}}$ was $80 \%$ if the score was $>12$ at the start and decreased to $<6$ under an elimination diet with extensive hydrolysate formula. ${ }^{13}$ After anonymous voting by an expert panel, consensus was reached for all five SBS items, with a view that CoMiSS $^{\mathrm{TM}}$ could be used as an "awareness" tool for CMPA in a primary care setting. 
Two studies investigated the performance of CoMiSS ${ }^{\mathrm{TM}}$ in healthy infants aged $<6$ months with the aim of providing a scientific basis for the recommended CoMiSS ${ }^{\mathrm{TM}}$ cut-off of $>12 .{ }^{20,21}$ Vandenplas ${ }^{21}$ reported a median CoMiSS ${ }^{\mathrm{TM}}$ score of 3 in a cohort of 413 infants from Belgium (31.2\%), Italy (18.2\%), Poland (19.1\%) and Spain (31.5\%); median crying, regurgitation and eczema scores differed significantly across the age categories $\left(\mathrm{p}<0.001, \mathrm{p}=0.001, \mathrm{p}=0.039\right.$, respectively). Bigorajska ${ }^{20}$ reported a median CoMiSS ${ }^{\mathrm{TM}}$ score of 4 in a cohort of 226 infants in Poland; similarly, age impacted on individual crying $(\mathrm{p}=0.001)$ and stool scores $(\mathrm{p}<0.001)$. Neither study reported information on the infants with a positive CoMiSS ${ }^{\mathrm{TM}}$ (score $>12$ ) and it is not clear if some of the same infants were included in both studies.

Vandenplas $^{22}$ investigated the inter-rater (HCP vs parent) variability of CoMiSS ${ }^{\mathrm{TM}}$ in 148 Spanish infants. The absolute agreement was reported as excellent with an intraclass correlation coefficient (ICC) 0.981 (95\% CI $0.974-0.986, \mathrm{p}<0.001)$. In the second phase of the study, a parent filled in the CoMiSS ${ }^{\mathrm{TM}}$ during 3 consecutive days and was compared to the CoMiSS ${ }^{\mathrm{TM}}$ scored by the HCP to evaluate day-to-day variability in 72 infants; the ICC was excellent for parental prospective scores, 0.93 (95\% CI $0.90-0.96$; p < 0.001), but poorer between the HCP and parents on Day one versus Day 2, 0.53 (95\% CI 0.34-0.68; p < 0.001).

\section{Test accuracy studies}

Test accuracy of CoMiSS ${ }^{\mathrm{TM}}$ was evaluated in 5 studies; two evaluated the accuracy of the tool to predict a positive food challenge following an elimination diet, ${ }^{8,23}$ whilst three evaluated the test accuracy at presentation relative to results of confirmatory tests for CMPA. ${ }^{24-26}$ Characteristics of the methods used to apply CoMiSS $^{\mathrm{TM}}$ and reference standards used in each study are presented in Table 2. Accuracy results for each study are summarised in Table 3 and Figure 5.

Of the two studies evaluating test accuracy in response to elimination diet, one evaluated CoMiSS ${ }^{\mathrm{TM}}$ in infants aged 0-10 months with a prior diagnosis of CMPA against OFC or skin prick test in infants $<6$ months of age. ${ }^{8}$ Authors reported that a [?]50\% decrease in CoMiSS ${ }^{\mathrm{TM}}$ score had sensitivity of $84 \%(95 \% \mathrm{CI}$ $70 \%$ to $93 \%$ ) but due to study design were unable to evaluate specificity. The lack of a healthy infant arm in this two-gate study design, leads to potentially misleading accuracy estimates. High sensitivity naturally leads to low specificity, and so would generate more false positive results. The second study comprised of 85 formula-fed infants aged 0-6 months with a baseline CoMiSS ${ }^{\mathrm{TM}}$ score of [?]12 (mean +- SD 13.65 +- 1.75; range 12-21). Authors reported that CoMiSS ${ }^{\mathrm{TM}}$ score [?]12 at presentation and $<6$ after 1-month elimination diet had sensitivity of $76 \%$ (95\% CI $63 \%$ to $86 \%$ ) and specificity of $58 \%$ (95\% CI $37 \%$ to $77 \%$ ) in predicting a positive OFC. ${ }^{23}$

Of the three studies evaluating test accuracy at presentation, one examined CoMiSS ${ }^{\mathrm{TM}}$ against either OFC or an immunology test (ImmunoCAP) ${ }^{26}$ This study of 83 infants aged 0-24 months reported moderate sensitivity of $79 \%$ (95\% CI $67 \%$ to $87 \%$ ) but low specificity of $38 \%$ (95\% CI 14\% to $68 \%$ ). A second study evaluated CoMiSS $^{\mathrm{TM}}$ against OFC in infants aged 1-12 months and through ROC-analysis reported a moderate to high sensitivity and specificity of $88 \%$ (95\% CI $68 \%$ to $97 \%$ ) and $79 \%$ (95\%CI $49 \%$ to $95 \%$ ), respectively, with a best diagnostic cut-off point of 5.5. ${ }^{24}$ The third examined CoMiSS ${ }^{\mathrm{TM}}$ against response to cow's milk free diet without performing an OFC. ${ }^{25}$ In 47 infants aged 1-12 months, authors reported poor sensitivity of $37 \%$ (95\% CI $16 \%$ to $62 \%$ ) but high specificity of $93 \%$, (95\% CI $75 \%$ to $99 \%)$ with a cut-off score of 12 . On ROC analysis a score of 9 was identified as the best diagnostic cut-off point, which results in an improved sensitivity $84 \%$ (95\%CI $60 \%$ to $97 \%$ ) and only slightly reduced specificity of $85 \%$ (95\%CI $67 \%$ to $96 \%$ ). However, the reported accuracy estimates are likely to overestimate the real performance of the score, first because response to elimination diet was defined as a decrease in the CoMiSS ${ }^{\mathrm{TM}}$ score (incorporation bias) and the cutoff of 9 was based on ROC analysis. 


\section{Effectiveness studies using symptom scores as an outcome}

Five studies reported use of CoMiSS ${ }^{\mathrm{TM}}$ as an outcome measure (see Table 5). In all studies, after symptomatic infants were administered cow's milk free formula, there was a significant change in CoMiSS ${ }^{\mathrm{TM}}$ score. $^{27-31}$

\section{CMPA questionnaire}

One study developed a questionnaire as a means of investigation. ${ }^{7}$ This was a pilot study which reported data on the internal validation of the tool. A citation search on Gibbons yielded four journal articles, none of which reported further evaluation of the tool. Characteristics of the pilot study are presented in Table 2. Sensitivity and specificity test pairs are presented in Table 3 and Figure 5. Authors evaluated test accuracy of the questionnaire at presentation relative to the results of an elimination diet in a cohort of 84 infants $<24$ months; 43 cases of infants with non-IgE mediated CMPA and 41 healthy controls. Authors reported ROC-determined estimates for sensitivity and specificity of $88 \%$ (95\%CI $75 \%$ to $96 \%$ ) and $71 \%$ (95\%CI $54 \%$ to $84 \%$ ), respectively, with a best diagnostic cut-off of [?] 6. Feasibility, in terms of time spent applying the questionnaire in a clinical setting, was evaluated as a secondary measure. Authors reported a range of 3 to 6 minutes to apply the questionnaire, which was deemed feasible in this setting.

\section{Discussion}

Symptom scores have been suggested to improve diagnosis of CMPA in infants by helping clinicians to recognise the symptoms of CMPA and establish the need for conclusive testing. We found two such scores evaluated in one and fourteen studies, respectively. These comprised evaluations of test accuracy, effectiveness studies using CoMiSS ${ }^{\mathrm{TM}}$ as an outcome measure, and aspects of the development and piloting of CoMiSS ${ }^{\mathrm{TM}}$. No end-to-end studies investigating the long-term outcomes of infants or economic evaluations were identified. Estimated sensitivity and specificity of the two symptom scores ranged from $37-98 \%$ and $38-93 \%$, respectively.

Although we identified a number of studies evaluating the accuracy of the scores, especially CoMiSS ${ }^{\mathrm{TM}}$, we are unable to report valid estimates of their sensitivity and specificity. Not only were all studies deemed to be at high risk of bias, but they were also of limited applicability and produced highly heterogeneous results. In line with our decision not to pool the results given the extensive heterogeneity, one study evaluating the predictive value of CoMiSS ${ }^{\mathrm{TM}}$ after elimination diet using pooled data from three clinical trials was excluded from this review due to inappropriate pooling and poor reporting of findings. ${ }^{32}$ The accuracy of a test is highly dependent on the conditions in which the test is used. Factors such as patient profile, previous tests and the skills and experience of the test operator could have a significant impact on the performance of the test and are likely to vary from setting to setting. Also, a different level of accuracy and balance between false positive and false negative rate will be required depending on the test's role in the diagnostic pathway. For this reason, the best approach in test evaluation is to define the role of the test from the very start and to be clear about the value proposition made for the new test: What are the expected benefits from the test compared to the current clinical practice? Given the above, the limitations of the studies included in the review could be summarised as follows.

The role of the test in the diagnostic pathway is unclear. Although CoMiSS ${ }^{\mathrm{TM}}$ is defined as an "awareness tool" and not for diagnosis of CMPA, it is not clear how exactly clinicians should use the test and make decisions for further testing, treatment, or ruling out of CMPA. The ambiguous nature of this definition of CoMiSS $^{\mathrm{TM}}$ is therefore a major limitation for the evaluation of its accuracy and impact. Initial suspicion of CMPA is usually based on one or more of the symptoms included in the symptom score so CoMiSS ${ }^{\mathrm{TM}}$ could be used at presentation to help clinicians make a more structured assessment of unexplained symptoms suggestive of CMPA. Applying the score could lead either to a negative result (ruling out CMPA) which requires high sensitivity and negative predictive value; or to further tests, such as elimination diet followed 
by OFC. Throughout the papers, authors point out that CoMiSS ${ }^{\mathrm{TM}}$ is not intended for diagnosis of CMPA or as a replacement for OFC. However, ruling out CMPA is an essential part of the diagnostic process to avoid unnecessary referrals for OFC.

In the UK, clinicians should follow the NICE CG116 when diagnosing infants suspected of CMPA. ${ }^{11}$ As with other national and international guidelines, the recommended first step is allergy-focused history not only to decide whether or not the symptoms are likely to be caused by CMPA, but also to decide on what type of CMPA is more likely and whether IgE tests should be carried out prior to elimination diet and OFC. It is therefore important to consider how the results would be used relative to other clinical information such as family history of atopy, which is absent from $\mathrm{CoMiSS}^{\mathrm{TM}}$, yet a significant indicator of allergy in children, and SIgE or SPT as detailed in the NICE guidance. ${ }^{11}$ Studies performed on presumed healthy infants failed to provide information on those who scored a CoMiSS ${ }^{\mathrm{TM}}>12$, which could demonstrate the lack of guidance on how to follow these infants up.

Another suggested use of the test is for monitoring symptoms during elimination diet and as a measure of change between baseline and follow up. The advantage of using a structured symptom score is that it is less subjective and open to individual interpretations and bias. A study evaluating the clinician-parent inter-rater agreement of CoMiSS ${ }^{\mathrm{TM}}$ reported positive results and also provided some limited evidence of good consistency over time. Some authors report that it is not possible to detect a clinically useful difference between the score at baseline in children with and without CMPA, but that a score of $<6$ after 1-month of elimination diet might be predictive of CMPA. ${ }^{28}$ However, such use may be limited given that the score is unable to provide conclusive results following an elimination diet, and an OFC is still required. In many of the studies, a significant proportion of parents $(\sim 20 \%)$ declined OFC once symptoms became less severe or completely disappeared. We know from epidemiological studies, such as EuroPrevall, that false positives are possible with elimination diet, and that elimination diet alone is not an acceptable diagnostic pathway. ${ }^{33}$ Where OFC is refused, the change in symptom score could be used to provide reassurance to parents that CMPA is likely and that further investigations are necessary. This specific use of the test requires further evaluation, in particular, where the error rate could be accurately measured.

Nestle suggest another role for CoMiSS ${ }^{\mathrm{TM}}$ in that it could be filled out by parents in preparation for visiting the GP. Again, at present, no studies have been conducted with this role in mind and the impact of using the test in this way is unclear. This specific role should be investigated in future studies before parents are advised to use it. Nestle state that the score is not to be used for diagnosis or in place of OFC, however, its use by parents could equally cause unintended effects, such as over-diagnosis and over-treatment of CMPA.

Once the role of the test is defined and the value proposition over current practice is clear, the test needs to be evaluated in good quality studies that go beyond accuracy and look at the impact of testing on patient outcomes and cost-effectiveness of alternative diagnostic-treatment pathways. Longitudinal studies are particularly important to establish how the results of the test are used alongside other clinical information in the diagnostic work-up for CMPA. Such studies need to consider the recruitment of relevant patients, given the pre-specified role of the test; the skills and expertise expected from clinicians who will be using the test, and any training requirements; provisions to deal with attrition bias, given that most studies reported high dropout rates; use of DBPCFC as a reference standard, to provide robust diagnosis of CMPA. Despite some evidence to suggest that it may not be appropriate to be performed in infants, DBPCFC is the optimum reference standard test for confirmation of CMPA in children. ${ }^{34}$ Our definition of applicability of the reference standard was one that aims to diagnose CMPA, however, further elaboration on the issue of applicability of reference standards other than DBPCFC may be necessary in future studies.

The strengths of this review include the use of internationally recommended methods for study identification and methodological quality assessment and a pre-specified protocol was registered on PROSPERO. The main limitation was the poor reporting and quality of included studies, and that too few, heterogenous studies were identified to perform meta-analysis. 


\section{Conclusions}

Just two tools for the diagnosis of CMPA were identified. The evaluations of these were either at high risk of bias or failed to address key issues such as clinical and cost-effectiveness. Estimates of accuracy offered so far should therefore be interpreted extremely cautiously. Rigorous research based on a well-defined role for the tools and free of potential conflicts of interest is urgently required.

\section{Author contributions}

GT contributed to search strategy, data collection, data analysis and manuscript. ZZ contributed to the study design, data collection, data analysis and manuscript. JP contributed to the study design, data collection, data analysis and manuscript. SK contributed data collection and manuscript. SB contributed to the search strategy and study design. LS, MN and SL contributed to study design and development of the protocol. CH contributed to the study design, data analysis and manuscript. All authors read and approved the final manuscript.

\section{Funding}

None declared

\section{Conflicts of interest}

None declared

Word count: 4181

\section{References}

1. Grimshaw KEC, Bryant T, Oliver EM, et al. Incidence and risk factors for food hypersensitivity in UK infants: Results from a birth cohort study. Clinical and Translational Allergy. 2016;6(1):1.

2. Walsh J, Meyer R, Shah N, Quekett J, Fox AT. Differentiating milk allergy (IgE and non-IgE mediated) from lactose intolerance: understanding the underlying mechanisms and presentations. $\mathrm{Br} J$ Gen Pract. 2016;66(649):e609-e611.

3. Walsh J, O'Flynn N. Diagnosis and assessment of food allergy in children and young people in primary care and community settings: NICE clinical guideline. Br J Gen Pract. 2011;61(588):473-475.

4. Sladkevicius E, Nagy E, Lack G, Guest JF. Resource implications and budget impact of managing cow milk allergy in the UK. Journal of Medical Economics. 2010;13(1).

5. Soares-Weiser K, Takwoingi Y, Panesar SS, et al. The diagnosis of food allergy: a systematic review and meta-analysis. Allergy.2014;69(1):76-86.

6. Flabbee J, Petit N, Jay N, et al. The economic costs of severe anaphylaxis in France: an inquiry carried out by the Allergy Vigilance Network. Allergy. 2008;63(3):360-365.

7. Gibbons TE, Patil SN, Frem JC, Smith C, Wakwe J, Swearingen CJ. Non-IgE-mediated cow milk allergy is linked to early childhood clusters of commonly seen illnesses: a pilot study. Clinical pediatrics.2012;51(4):337344.

8. Sirin Kose S, Atakul G, Asilsoy S, Uzuner N, Anal O, Karaman O. The efficiency of the symptom-based score in infants diagnosed with cow's milk protein and hen's egg allergy. Allergologia et Immunopathologia. 2019;47(3):265-271. 
9. Lozinsky AC, Meyer R, Anagnostou K, et al. Cow's Milk Protein Allergy from Diagnosis to Management: A Very Different Journey for General Practitioners and Parents. Children (Basel). 2015;2(3):317-329.

10. Sicherer SH, Sampson HA. Food allergy: A review and update on epidemiology, pathogenesis, diagnosis, prevention, and management. Journal of Allergy and Clinical Immunology 2018;141(1):41-58.

11. Venter C, Arshad SH. Guideline fever: an overview of DRACMA, US NIAID and UK NICE guidelines. Curr Opin Allergy Clin Immunol.2012;12(3):302-315.

12. Cerecedo I, Zamora J, Fox M, et al. The impact of double-blind placebo- controlled food challenge (DBPCFC) on the socioeconomic cost of food allergy in Europe. Journal of investigational allergology 83 clinical immunology. 2014;24(6):418-424.

13. Vandenplas Y, Dupont C, Eigenmann P, et al. A workshop report on the development of the Cow's Milk-related Symptom Score awareness tool for young children. Acta Paediatrica, International Journal of Paediatrics. 2015;104(4):334-339.

14. van Tulleken C. Overdiagnosis and industry influence: how cow's milk protein allergy is extending the reach of infant formula manufacturers. BMJ. 2018;363:k5056.

15. Higgins JPT, Thomas J, Chandler J, et al. Cochrane Handbook for Systematic Reviews of Interventions. In: 2nd ed. Chichester (UK): John Wiley \& Sons; 2019.

16. Moons K, Wolff R, Riley R, et al. PROBAST: A Tool to Assess Risk of Bias and Applicability of Prediction Model Studies: Explanation and Elaboration. Annals of Internal Medicine. 2019;170(1):W1.

17. Whiting PF, Rutjes AWS, Westwood ME, et al. QUADAS-2: a revised tool for the quality assessment of diagnostic accuracy studies. Annals of Internal Medicine. 2011;155(8):529-536.

18. Deeks J, Gatsonis Ce. Cochrane Handbook for Systematic Reviews of Diagnostic Test Accuracy. 1.0.0 ed: The Cochrane Collaboration; 2013.

19. The Cow's Milk-related Symptom Score CoMiSS(TM). In: Nestle Health Science 2015: NestleHealthScience.com/CoMiSS.

20. Bigorajska K, Filipiak Z, Winiarska P, et al. Cow's Milk-Related Symptom Score in Presumed Healthy Polish Infants Aged 0-6 Months.Paediatric Gastroenterology, Hepatology \&6 Nutrition.2020;23(2):154-162.

21. Vandenplas Y, Salvatore S, Ribes-Koninckx C, Carvajal E, Szajewska H, Huysentruyt K. The cow milk symptom score (CoMiSSTM) in presumed healthy infants. PLoS ONE. 2018;13(7):e0200603.

22. Vandenplas Y, Carvajal E, Peeters S, et al. The Cow's Milk-Related Symptom Score (CoMiSS(TM)): Health Care Professional and Parent and Day-to-Day Variability. Nutrients. 2020;12(2):438.

23. Vandenplas Y, Althera Study G, Steenhout P, Grathwohl D. A pilot study on the application of a symptom-based score for the diagnosis of cow's milk protein allergy. SAGE open medicine.2014;2:2050312114523423.

24. Zeng Y, Zhang J, Dong G, et al. Assessment of Cow's milk-related symptom scores in early identification of cow's milk protein allergy in Chinese infants. BMC Pediatrics. 2019;19(1):191.

25. Salvatore S, Bertoni E, Bogni F, et al. Testing the cow's milk-related symptom score (CoMissTM) for the response to a cow's milk-free diet in infants: A prospective study. Nutrients.2019;11(10):2402.

26. Prasad R, Venkata RSA, Ghokale P, Chakravarty P, Anwar F. Cow's Milk-related symptom Score as a predictive tool for cow's milk allergy in Indian children aged 0-24 months. Asia Pacific Allergy.2018;8(4):e36.

27. Dupont C, Bradatan E, Soulaines P, Nocerino R, Berni-Canani R. Tolerance and growth in children with cow's milk allergy fed a thickened extensively hydrolyzed casein-based formula. BMC Pediatrics.2016;16(1):96. 
28. Vandenplas Y, De Greef E. Extensive protein hydrolysate formula effectively reduces regurgitation in infants with positive and negative challenge tests for cow's milk allergy. Acta Paediatrica, International Journal of Paediatrics. 2014;103(6):e243-e250.

29. Vandenplas Y, De Greef E, Hauser B. Safety and tolerance of a new extensively hydrolyzed rice proteinbased formula in the management of infants with cow's milk protein allergy. European Journal of Pediatrics. 2014;173(9):1209-1216.

30. Vandenplas Y, Steenhout P, Planoudis Y, Grathwohl D. Treating cow's milk protein allergy: A doubleblind randomized trial comparing two extensively hydrolysed formulas with probiotics. Acta Paediatrica, International Journal of Paediatrics. 2013;102(10):990-998.

31. Rossetti D, Cucchiara S, Morace A, Leter B, Oliva S. Hypoallergenicity of a thickened hydrolyzed formula in children with cow's milk allergy. World journal of clinical cases.2019;7(16):2256-2268.

32. Vandenplas Y, Steenhout P, Jarvi A, Garreau A-S, Mukherjee R. Pooled Analysis of the Cow's Milkrelated-Symptom-Score (CoMiSSTM) as a Predictor for Cow's Milk Related Symptoms. Pediatric gastroenterology, hepatology \& nutrition. 2017;20(1):22-26.

33. Schoemaker AA, Sprikkelman AB, Grimshaw K, et al. Incidence and natural history of challenge-proven cow's milk allergy in European children-EuroPrevall birth cohort. Allergy.2015;70(8):963-972.

34. Vandenplas Y, Koletzko S, Isolauri E, et al. Guidelines for the diagnosis and management of cow's milk protein allergy in infants. Archives of disease in childhood. 2007;92(10):902-908.

Table 1 : Summary of included studies.

\section{Study}

Bigorajska, 2020

Dupont, 2016

Gibbons, 2012

Prasad, 2018

Rossetti, 2019

Salvatore, 2019

Sirin Kose, 2019

Vandenplas, 2013

Vandenplas, 2014

Vandenplas, 2014

Vandenplas, 2014

Vandenplas, 2015

Vandenplas, 2018

Vandenplas, 2019

Zeng, 2019

CMFD - cow's milk free diet CMPA - cow's milk protein allergy DTA - diagnostic test accuracy eCH - extensive casein hy

Table 2 : Summary of characteristics of diagnostic test accuracy studies on CMPA questionnaire and CoMiSS $^{\mathrm{TM}}$.

\begin{tabular}{llllll}
\hline Study & $\begin{array}{l}\text { Inclusion } \\
\text { criteria and } \\
\text { selection }\end{array}$ & $\begin{array}{l}\text { Index test } \\
\text { cut-off }\end{array}$ & $\begin{array}{l}\text { Index test } \\
\text { examiner }\end{array}$ & $\begin{array}{l}\text { Reference } \\
\text { standard(s) }\end{array}$ & $\begin{array}{l}\text { Definition of } \\
\text { CMPA by } \\
\text { reference } \\
\text { standard }\end{array}$ \\
$\begin{array}{l}\text { CMPA } \\
\text { questionnaire }\end{array}$ & $\begin{array}{l}\text { CMPA } \\
\text { questionnaire }\end{array}$ & $\begin{array}{l}\text { CMPA } \\
\text { questionnaire }\end{array}$ & $\begin{array}{l}\text { CMPA } \\
\text { questionnaire }\end{array}$ & $\begin{array}{l}\text { CMPA } \\
\text { questionnaire }\end{array}$ & $\begin{array}{l}\text { CMPA } \\
\text { questionnaire }\end{array}$
\end{tabular}




\begin{tabular}{|c|c|c|c|c|c|}
\hline Gibbons, 2012 & $\begin{array}{l}\text { Case-control: } \\
\text { infants }<2 \\
\text { years seen at } \\
\text { gastroenterol- } \\
\text { ogy clinic with } \\
\text { a diagnosis of } \\
\text { CMPA \& } \\
\text { presumed } \\
\text { healthy } \\
\text { controls seen } \\
\text { at routine } \\
\text { health visit }\end{array}$ & $\begin{array}{l}\text { ROC- } \\
\text { determined: } \\
\text { score }>6\end{array}$ & $\begin{array}{l}\text { Health } \\
\text { professional }\end{array}$ & $\begin{array}{l}\text { Elimination } \\
\text { diet }+ \\
\text { ImmunoCAP }\end{array}$ & $\begin{array}{l}\text { Positive } \\
\text { response to } \\
\text { diet }+ \text { test } \\
\text { negative for } \\
\text { IgE mediated } \\
\text { disease }+ \\
\text { failed } \\
\text { management } \\
\text { of alternative } \\
\text { conditions }\end{array}$ \\
\hline $\begin{array}{l}\text { CoMiSS }{ }^{\mathrm{TM}} \\
\left(^{+} \text {or its earlier }\right.\end{array}$ & $\begin{array}{l}\text { CoMiSS } \\
\left(^{+} \text {or its earlier }\right.\end{array}$ & $\begin{array}{l}\text { CoMiSS }{ }^{\mathrm{TM}} \\
\text { ( }^{+} \text {or its earlier }\end{array}$ & $\begin{array}{l}\text { CoMiSS }^{\mathrm{TM}} \\
\text { ( }^{+} \text {or its earlier }\end{array}$ & $\begin{array}{l}\text { CoMiSS } \\
\left(^{+} \text {or its earlier }\right.\end{array}$ & $\begin{array}{l}\text { CoMiSS }^{\mathrm{TM}} \\
\left(^{+} \text {or its earlier }\right.\end{array}$ \\
\hline Salvatore, 2019 & $\begin{array}{l}\text { Case-control: } \\
\text { infants aged 1-12 } \\
\text { months seen at } \\
\text { gastroenterology } \\
\text { clinic with } \\
\text { suspected CMPA } \\
\text { and who started } \\
\text { CMFD for } \\
\text { persistent GI } \\
\text { symptoms \& } \\
\text { healthy controls }\end{array}$ & $\begin{array}{l}\text { Pre-specified: } \\
\text { score > } 12 \\
\text { ROC- } \\
\text { determined: } \\
\text { score > } 9\end{array}$ & Paediatrician & $\begin{array}{l}\text { Response to } \\
\text { CMFD }\end{array}$ & $\begin{array}{l}\text { Change in } \\
\text { CoMiSS } \\
\text { of symptomatic } \\
\text { infants at } \\
\text { presentation to a } \\
\text { score below the } \\
\text { median of } \\
\text { control } \\
\text { population after } \\
2-4 \text { weeks CMFD }\end{array}$ \\
\hline $\begin{array}{l}\text { Sirin Kose, } \\
2019^{+}\end{array}$ & $\begin{array}{l}\text { Infants aged } \\
0-10 \text { months } \\
\text { with a } \\
\text { diagnosis of } \\
\text { CMPA or } \\
\text { HEA or both } \\
\text { presenting to } \\
\text { paediatric } \\
\text { allergy clinic } \\
\text { and with SBS } \\
>12\end{array}$ & $\begin{array}{l}\text { Pre-specified: } \\
\text { score }>12 \\
\text { with reduction } \\
\text { of } 25 \% \text { or } \\
\text { score }>10 \\
\text { with reduction } \\
\text { of } 50 \%\end{array}$ & $\begin{array}{l}\text { Medical } \\
\text { supervision }\end{array}$ & $\begin{array}{l}\text { OFC or skin } \\
\text { prick test in } \\
\text { infants }<6 \\
\text { months }\end{array}$ & $\begin{array}{l}\text { Positive if } \\
\text { symptoms } \\
\text { reoccur } \\
\text { following } \\
\text { OFC, positive } \\
\text { skin prick with } \\
\text { wheal }>3 \mathrm{~mm}\end{array}$ \\
\hline
\end{tabular}




\begin{tabular}{|c|c|c|c|c|c|}
\hline $\begin{array}{l}\text { Vandenplas, } \\
2014^{+}\end{array}$ & $\begin{array}{l}\text { Infants aged } \\
0-6 \text { months } \\
\text { presenting } \\
\text { with } \\
\text { symptoms of } \\
\text { mild to } \\
\text { moderate } \\
\text { CMPA and } \\
\text { with SBS > } 12\end{array}$ & $\begin{array}{l}\text { ROC- } \\
\text { determined: } \\
\text { score }>12 \\
\text { baseline to } \\
\text { score }<6 \text { after } \\
\text { elimination }\end{array}$ & Physician & $\mathrm{OFC}$ & $\begin{array}{l}\text { Positive if } \\
\text { symptoms } \\
\text { reoccur within } \\
1 \text { week of OFC }\end{array}$ \\
\hline Zeng, 2019 & $\begin{array}{l}\text { Infants aged } \\
1-12 \text { months } \\
\text { seen at } \\
\text { paediatric GI } \\
\text { clinic for } \\
\text { suspected } \\
\text { CMPA with at } \\
\text { least one } \\
\text { symptom, } \\
\text { including } \\
\text { anaphylaxis, } \\
\text { GI, respiratory } \\
\text { and } \\
\text { dermatological } \\
\text { manifesta- } \\
\text { tions, and sIgE } \\
<5.0 \mathrm{kU} / \mathrm{L}\end{array}$ & $\begin{array}{l}\text { ROC- } \\
\text { determined: } \\
\text { score > }>.5\end{array}$ & GI physician & $\mathrm{OFC}$ & $\begin{array}{l}\text { Positive if } \\
\text { symptoms } \\
\text { reappear } \\
\text { within } 2 \text { weeks } \\
\text { of OFC }\end{array}$ \\
\hline CMFD - cow's & CMFD - cow's & CMFD - cow's & CMFD - cow's & CMFD - cow's & CMFD - cow's \\
\hline milk free diet & milk free diet & milk free diet & milk free diet & milk free diet & milk free diet \\
\hline CMPA - cow's & CMPA - cow's & CMPA - cow's & CMPA - cow's & CMPA - cow's & CMPA - cow's \\
\hline milk protein & milk protein & milk protein & milk protein & milk protein & milk protein \\
\hline allergy HEA - & allergy HEA - & allergy HEA - & allergy HEA - & allergy HEA - & allergy HEA - \\
\hline hen's egg & hen's egg & hen's egg & hen's egg & hen's egg & hen's egg \\
\hline $\begin{array}{l}\text { allergy GI - } \\
\text { gastrointesti- } \\
\text { nal OFC - oral } \\
\text { food challenge }\end{array}$ & $\begin{array}{l}\text { allergy GI - } \\
\text { gastrointesti- } \\
\text { nal OFC - oral } \\
\text { food challenge }\end{array}$ & $\begin{array}{l}\text { allergy GI - } \\
\text { gastrointesti- } \\
\text { nal OFC - oral } \\
\text { food challenge }\end{array}$ & $\begin{array}{l}\text { allergy GI - } \\
\text { gastrointesti- } \\
\text { nal OFC - oral } \\
\text { food challenge }\end{array}$ & $\begin{array}{l}\text { allergy GI - } \\
\text { gastrointesti- } \\
\text { nal OFC - oral } \\
\text { food challenge }\end{array}$ & $\begin{array}{l}\text { allergy GI - } \\
\text { gastrointesti- } \\
\text { nal OFC - oral } \\
\text { food challenge }\end{array}$ \\
\hline $\begin{array}{l}\mathrm{ROC}- \\
\text { receiver }\end{array}$ & $\begin{array}{l}\mathrm{ROC}- \\
\text { receiver }\end{array}$ & $\begin{array}{l}\mathrm{ROC}- \\
\text { receiver }\end{array}$ & $\begin{array}{l}\mathrm{ROC}- \\
\text { receiver }\end{array}$ & $\begin{array}{l}\mathrm{ROC}- \\
\text { receiver }\end{array}$ & $\begin{array}{l}\mathrm{ROC}- \\
\text { receiver }\end{array}$ \\
\hline operating & operating & operating & operating & operating & operating \\
\hline $\begin{array}{l}\text { curve sIgE - } \\
\text { serum IgE SBS }\end{array}$ & $\begin{array}{l}\text { curve sIgE - } \\
\text { serum IgE SBS }\end{array}$ & $\begin{array}{l}\text { curve sIgE - } \\
\text { serum IgE SBS }\end{array}$ & $\begin{array}{l}\text { curve sIgE - } \\
\text { serum IgE SBS }\end{array}$ & $\begin{array}{l}\text { curve sIgE - } \\
\text { serum IgE SBS }\end{array}$ & $\begin{array}{l}\text { curve sIgE - } \\
\text { serum IgE SBS }\end{array}$ \\
\hline $\begin{array}{l}\text { - symptom- } \\
\text { based }\end{array}$ & $\begin{array}{l}\text { - symptom- } \\
\text { based }\end{array}$ & $\begin{array}{l}\text { - symptom- } \\
\text { based }\end{array}$ & $\begin{array}{l}\text { - symptom- } \\
\text { based }\end{array}$ & $\begin{array}{l}\text { - symptom- } \\
\text { based }\end{array}$ & $\begin{array}{l}\text { - symptom- } \\
\text { based }\end{array}$ \\
\hline score & score & score & score & score & score \\
\hline
\end{tabular}

Table 3. Summary of test accuracies reported by diagnostic test accuracy studies on CMPA questionnaire and $\mathrm{CoMiSS}^{\mathrm{TM}}$. 


\begin{tabular}{|c|c|c|c|c|c|c|c|c|c|}
\hline Study & $\begin{array}{l}\text { Score at } \\
\text { presen- } \\
\text { tation, } \\
\text { Mean } \pm \\
\text { SD / } \\
\text { Median } \\
{[\text { IQR] }}\end{array}$ & $\begin{array}{l}\text { Cut-off } \\
\text { score }\end{array}$ & $\begin{array}{l}\text { Total } \\
\text { infants } \\
\text { in- } \\
\text { cluded } \\
\text { in } \\
\text { analysis }\end{array}$ & $\begin{array}{l}\text { Total } \\
\text { patients } \\
\text { with } \\
\text { con- } \\
\text { firmed } \\
\text { CMPA, } \\
\% \\
\text { preva- } \\
\text { lence }\end{array}$ & $\mathbf{T P}$ & FP & $\mathbf{F N}$ & TN & $\begin{array}{l}\text { Sensitivity } \\
{[\mathbf{9 5 \%}} \\
\mathrm{CI}]\end{array}$ \\
\hline $\begin{array}{l}\text { CMPA } \\
\text { ques- } \\
\text { tion- } \\
\text { naire }\end{array}$ & $\begin{array}{l}\text { CMPA } \\
\text { ques- } \\
\text { tion- } \\
\text { naire }\end{array}$ & $\begin{array}{l}\text { CMPA } \\
\text { ques- } \\
\text { tion- } \\
\text { naire }\end{array}$ & $\begin{array}{l}\text { CMPA } \\
\text { ques- } \\
\text { tion- } \\
\text { naire }\end{array}$ & $\begin{array}{l}\text { CMPA } \\
\text { ques- } \\
\text { tion- } \\
\text { naire }\end{array}$ & $\begin{array}{l}\text { CMPA } \\
\text { ques- } \\
\text { tion- } \\
\text { naire }\end{array}$ & $\begin{array}{l}\text { CMPA } \\
\text { ques- } \\
\text { tion- } \\
\text { naire }\end{array}$ & $\begin{array}{l}\text { CMPA } \\
\text { ques- } \\
\text { tion- } \\
\text { naire }\end{array}$ & $\begin{array}{l}\text { CMPA } \\
\text { ques- } \\
\text { tion- } \\
\text { naire }\end{array}$ & $\begin{array}{l}\text { CMPA } \\
\text { ques- } \\
\text { tion- } \\
\text { naire }\end{array}$ \\
\hline $\begin{array}{l}\text { Gibbons, } \\
2012\end{array}$ & $\begin{array}{l}10.7 \pm \\
4.3 \mathrm{in} \\
\text { cases } 3.7 \\
\pm 2.8 \mathrm{in} \\
\text { controls }\end{array}$ & $\begin{array}{l}{[?] 6} \\
(\max 24)\end{array}$ & 84 & $\begin{array}{l}51 \% \\
(43 / 84)\end{array}$ & 38 & 12 & 5 & 29 & $\begin{array}{l}0.88 \\
{[0.75} \\
0.96]\end{array}$ \\
\hline $\begin{array}{l}\text { Gibbons, } \\
2012\end{array}$ & $\begin{array}{l}8.7 \pm 3.3 \\
\text { in cases } \\
2.3 \pm 2.2 \\
\text { in } \\
\text { controls }\end{array}$ & $\begin{array}{l}{[?] 6} \\
(\max 15)\end{array}$ & 84 & $\begin{array}{l}51 \% \\
(43 / 84)\end{array}$ & 38 & 3 & 9 & 38 & $\begin{array}{l}0.81 \\
{[0.67} \\
0.91]\end{array}$ \\
\hline $\begin{array}{l}\text { CoMiSS } \\
\left(^{+} \text {or }\right.\end{array}$ & $\begin{array}{l}\text { CoMiSS }^{\mathrm{TM}} \\
\left(^{+} \text {or }\right.\end{array}$ & $\begin{array}{l}\text { CoMiSS }^{\mathrm{TM}} \\
\left(^{+} \text {or }\right.\end{array}$ & $\begin{array}{l}\mathrm{CoMiSS}^{\mathrm{TM}} \\
\left(^{+} \text {or }\right.\end{array}$ & $\begin{array}{l}\text { CoMiSS }^{\mathrm{TM}} \\
\left(^{+} \text {or }\right.\end{array}$ & $\begin{array}{l}\text { CoMiSS } \\
\left(^{+} \text {or }\right.\end{array}$ & $\begin{array}{l}\text { CoMiSS }^{\mathrm{TM}} \\
\left(^{+} \text {or }\right.\end{array}$ & $\begin{array}{l}\mathrm{CoMiSS}^{\mathrm{TM}} \\
\left(^{+} \text {or }\right.\end{array}$ & $\begin{array}{l}\text { CoMiSS }^{\mathrm{TM}} \\
\left(^{+} \text {or }\right.\end{array}$ & $\begin{array}{l}\mathrm{CoMiSS}^{\mathrm{TM}} \\
\left(^{+} \text {or }\right.\end{array}$ \\
\hline its & its & its & its & its & its & its & its & its & its \\
\hline earlier & earlier & earlier & earlier & earlier & earlier & earlier & earlier & earlier & earlier \\
\hline$S B S$ & $S B S$ & $S B S$ & $S B S$ & $S B S$ & $S B S$ & $S B S$ & $S B S$ & $S B S$ & $S B S$ \\
\hline $\begin{array}{l}\text { ver- } \\
\text { sion) } \\
\text { At }\end{array}$ & $\begin{array}{l}\text { ver- } \\
\text { sion) } \\
\text { At }\end{array}$ & $\begin{array}{l}\text { ver- } \\
\text { sion) } \\
\text { At }\end{array}$ & $\begin{array}{l}\text { ver- } \\
\text { sion) } \\
\text { At }\end{array}$ & $\begin{array}{l}\text { ver- } \\
\text { sion) } \\
\text { At }\end{array}$ & $\begin{array}{l}\text { ver- } \\
\text { sion) } \\
\text { At }\end{array}$ & $\begin{array}{l}\text { ver- } \\
\text { sion) } \\
\text { At }\end{array}$ & $\begin{array}{l}\text { ver- } \\
\text { sion) } \\
\text { At }\end{array}$ & $\begin{array}{l}\text { ver- } \\
\text { sion) } \\
\text { At }\end{array}$ & $\begin{array}{l}\text { ver- } \\
\text { sion) } \\
\text { At }\end{array}$ \\
\hline present. & apresentat & ipresen & apre & 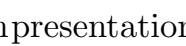 & & & & & \\
\hline $\begin{array}{l}\text { Prasad, } \\
2018^{++}\end{array}$ & $\begin{array}{l}16.2 \pm \\
6.8\end{array}$ & [?] 12 & 83 & $\begin{array}{l}84 \% \\
(70 / 83)\end{array}$ & 55 & 8 & 15 & 5 & $\begin{array}{l}0.79 \\
{[0.67} \\
0.87]\end{array}$ \\
\hline $\begin{array}{l}\text { Salvatore, } \\
2019\end{array}$ & $8[2-16]$ & {$[?] 9$} & 47 & $\begin{array}{l}40 \% \\
(19 / 47)\end{array}$ & 16 & 4 & 3 & 24 & $\begin{array}{l}0.84 \\
{[0.60} \\
0.97]\end{array}$ \\
\hline $\begin{array}{l}\text { Salvatore, } \\
2019\end{array}$ & $8[2-16]$ & [?] 12 & 47 & $\begin{array}{l}40 \% \\
(19 / 47)\end{array}$ & 7 & 2 & 12 & 26 & $\begin{array}{l}0.37 \\
{[0.16} \\
0.62]\end{array}$ \\
\hline $\begin{array}{l}\text { Sirin } \\
\text { Kose, } \\
2019^{+}\end{array}$ & $\begin{array}{l}13 \\
{[11-16]}\end{array}$ & [?] 10 & 49 & $\begin{array}{l}100 \% \\
(49 / 49)\end{array}$ & 43 & - & 6 & - & $\begin{array}{l}0.88 \\
{[0.75} \\
0.95]\end{array}$ \\
\hline $\begin{array}{l}\text { Sirin } \\
\text { Kose, } \\
2019^{+}\end{array}$ & $\begin{array}{l}13 \\
{[11-16]}\end{array}$ & [?] 12 & 49 & $\begin{array}{l}100 \% \\
(49 / 49)\end{array}$ & 34 & - & 15 & - & $\begin{array}{l}0.69 \\
{[0.55} \\
0.82]\end{array}$ \\
\hline $\begin{array}{l}\text { Vandenplas, } \\
2014^{+}\end{array}$ & $\begin{array}{l}13.65 \\
\pm 1.5\end{array}$ & [?] 12 & 84 & $\begin{array}{l}69 \% \\
(58 / 84)\end{array}$ & 58 & - & 26 & - & $\begin{array}{l}0.69 \\
{[0.58} \\
0.79]\end{array}$ \\
\hline
\end{tabular}




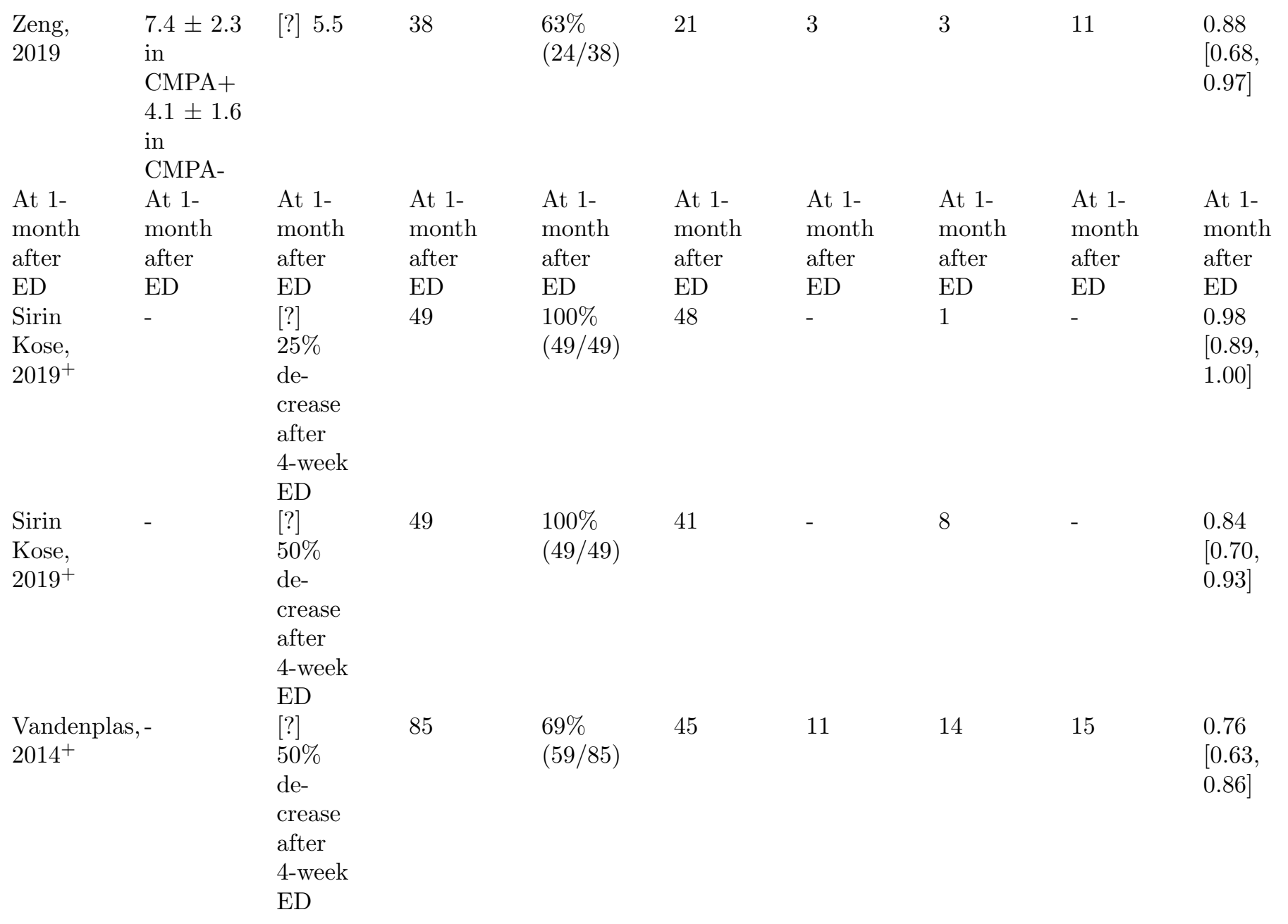




\begin{tabular}{|c|c|c|c|c|c|c|c|c|c|}
\hline $\begin{array}{l}++ \text { dis- } \\
\text { crepan- } \\
\text { cies in } \\
\text { the re- } \\
\text { ported } \\
\text { data }\end{array}$ & $\begin{array}{l}++ \text { dis- } \\
\text { crepan- } \\
\text { cies in } \\
\text { the re- } \\
\text { ported } \\
\text { data }\end{array}$ & $\begin{array}{l}++ \text { dis- } \\
\text { crepan- } \\
\text { cies in } \\
\text { the re- } \\
\text { ported } \\
\text { data }\end{array}$ & $\begin{array}{l}++ \text { dis- } \\
\text { crepan- } \\
\text { cies in } \\
\text { the re- } \\
\text { ported } \\
\text { data }\end{array}$ & $\begin{array}{l}++ \text { dis- } \\
\text { crepan- } \\
\text { cies in } \\
\text { the re- } \\
\text { ported } \\
\text { data }\end{array}$ & $\begin{array}{l}++ \text { dis- } \\
\text { crepan- } \\
\text { cies in } \\
\text { the re- } \\
\text { ported } \\
\text { data }\end{array}$ & $\begin{array}{l}++ \text { dis- } \\
\text { crepan- } \\
\text { cies in } \\
\text { the re- } \\
\text { ported } \\
\text { data }\end{array}$ & $\begin{array}{l}++ \text { dis- } \\
\text { crepan- } \\
\text { cies in } \\
\text { the re- } \\
\text { ported } \\
\text { data }\end{array}$ & $\begin{array}{l}++ \text { dis- } \\
\text { crepan- } \\
\text { cies in } \\
\text { the re- } \\
\text { ported } \\
\text { data }\end{array}$ & $\begin{array}{l}++ \text { dis- } \\
\text { crepan- } \\
\text { cies in } \\
\text { the re- } \\
\text { ported } \\
\text { data }\end{array}$ \\
\hline $\begin{array}{l}\text { were } \\
\text { identi- } \\
\text { fied. }\end{array}$ & $\begin{array}{l}\text { were } \\
\text { identi- } \\
\text { fied. }\end{array}$ & $\begin{array}{l}\text { were } \\
\text { identi- } \\
\text { fied. }\end{array}$ & $\begin{array}{l}\text { were } \\
\text { identi- } \\
\text { fied. }\end{array}$ & $\begin{array}{l}\text { were } \\
\text { identi- } \\
\text { fied. }\end{array}$ & $\begin{array}{l}\text { were } \\
\text { identi- } \\
\text { fied. }\end{array}$ & $\begin{array}{l}\text { were } \\
\text { identi- } \\
\text { fied. }\end{array}$ & $\begin{array}{l}\text { were } \\
\text { identi- } \\
\text { fied. }\end{array}$ & $\begin{array}{l}\text { were } \\
\text { identi- } \\
\text { fied. }\end{array}$ & $\begin{array}{l}\text { were } \\
\text { identi- } \\
\text { fied. }\end{array}$ \\
\hline $\begin{array}{l}\text { Pre- } \\
\text { sented }\end{array}$ & $\begin{array}{l}\text { Pre- } \\
\text { sented }\end{array}$ & $\begin{array}{l}\text { Pre- } \\
\text { sented }\end{array}$ & $\begin{array}{l}\text { Pre- } \\
\text { sented }\end{array}$ & $\begin{array}{l}\text { Pre- } \\
\text { sented }\end{array}$ & $\begin{array}{l}\text { Pre- } \\
\text { sented }\end{array}$ & $\begin{array}{l}\text { Pre- } \\
\text { sented }\end{array}$ & $\begin{array}{l}\text { Pre- } \\
\text { sented }\end{array}$ & $\begin{array}{l}\text { Pre- } \\
\text { sented }\end{array}$ & $\begin{array}{l}\text { Pre- } \\
\text { sented }\end{array}$ \\
\hline here is & here is & here is & here is & here is & here is & here is & here is & here is & here is \\
\hline the re- & the re- & the re- & the re- & the re- & the re- & the re- & the re- & the re- & the re- \\
\hline ported & ported & ported & ported & ported & ported & ported & ported & ported & ported \\
\hline two-by- & two-by- & two-by- & two-by- & two-by- & two-by- & two-by- & two-by- & two-by- & two-by- \\
\hline two & two & two & two & two & two & two & two & two & two \\
\hline data & data & data & data & data & data & data & data & data & data \\
\hline with & with & with & with & with & with & with & with & with & with \\
\hline test ac- & test ac- & test ac- & test ac- & test ac- & test ac- & test ac- & test ac- & test ac- & test ac- \\
\hline curacy & curacy & curacy & curacy & curacy & curacy & curacy & curacy & curacy & curacy \\
\hline $\begin{array}{l}\text { esti- } \\
\text { mates }\end{array}$ & $\begin{array}{l}\text { esti- } \\
\text { mates }\end{array}$ & $\begin{array}{l}\text { esti- } \\
\text { mates }\end{array}$ & $\begin{array}{l}\text { esti- } \\
\text { mates }\end{array}$ & $\begin{array}{l}\text { esti- } \\
\text { mates }\end{array}$ & $\begin{array}{l}\text { esti- } \\
\text { mates }\end{array}$ & $\begin{array}{l}\text { esti- } \\
\text { mates }\end{array}$ & $\begin{array}{l}\text { esti- } \\
\text { mates }\end{array}$ & $\begin{array}{l}\text { esti- } \\
\text { mates }\end{array}$ & $\begin{array}{l}\text { esti- } \\
\text { mates }\end{array}$ \\
\hline calcu- & calcu- & calcu- & calcu- & calcu- & calcu- & calcu- & calcu- & calcu- & calcu- \\
\hline lated & lated & lated & lated & lated & lated & lated & lated & lated & lated \\
\hline in & in & in & in & in & in & in & in & in & in \\
\hline Review & Review & Review & Review & Review & Review & Review & Review & Review & Review \\
\hline Man- & Man- & Man- & Man- & Man- & Man- & Man- & Man- & Man- & Man- \\
\hline ager. & ager. & ager. & ager. & ager. & ager. & ager. & ager. & ager. & ager. \\
\hline CMPA & CMPA & CMPA & CMPA & CMPA & CMPA & CMPA & CMPA & CMPA & CMPA \\
\hline - cow's & - cow's & - cow's & - cow's & - cow's & - cow's & - cow's & - cow's & - cow's & - cow's \\
\hline milk & milk & milk & milk & milk & milk & milk & milk & milk & milk \\
\hline protein & protein & protein & protein & protein & protein & protein & protein & protein & protein \\
\hline $\mathrm{ED}-$ & ED - & $\mathrm{ED}-$ & ED - & ED - & ED - & ED - & ED - & ED - & ED - \\
\hline elimi- & elimi- & elimi- & elimi- & elimi- & elimi- & elimi- & elimi- & elimi- & elimi- \\
\hline nation & nation & nation & nation & nation & nation & nation & nation & nation & nation \\
\hline diet & diet & diet & diet & diet & diet & diet & diet & diet & diet \\
\hline IQR - & IQR - & IQR - & IQR - & IQR - & IQR - & IQR - & IQR - & IQR - & IQR - \\
\hline inter- & inter- & inter- & inter- & inter- & inter- & inter- & inter- & inter- & inter- \\
\hline quartile & quartile & quartile & quartile & quartile & quartile & quartile & quartile & quartile & quartile \\
\hline range & range & range & range & range & range & range & range & range & range \\
\hline SBS - & SBS - & SBS - & SBS - & SBS - & SBS - & SBS - & SBS - & SBS - & SBS - \\
\hline $\begin{array}{l}\text { symptom- } \\
\text { based }\end{array}$ & $\begin{array}{l}\text { symptom- } \\
\text { based }\end{array}$ & $\begin{array}{l}\text { symptom- } \\
\text { based }\end{array}$ & $\begin{array}{l}\text { symptom- } \\
\text { based }\end{array}$ & $\begin{array}{l}\text { symptom- } \\
\text { based }\end{array}$ & $\begin{array}{l}\text { symptom- } \\
\text { based }\end{array}$ & $\begin{array}{l}\text { symptom- } \\
\text { based }\end{array}$ & $\begin{array}{l}\text { symptom- } \\
\text { based }\end{array}$ & $\begin{array}{l}\text { symptom- } \\
\text { based }\end{array}$ & $\begin{array}{l}\text { symptom- } \\
\text { based }\end{array}$ \\
\hline score & score & score & score & score & score & score & score & score & score \\
\hline $\mathrm{SD}-$ & $\mathrm{SD}-$ & $\mathrm{SD}-$ & $\mathrm{SD}-$ & $\mathrm{SD}-$ & $\mathrm{SD}-$ & $\mathrm{SD}-$ & $\mathrm{SD}-$ & $\mathrm{SD}-$ & SD - \\
\hline stan- & stan- & stan- & stan- & stan- & stan- & stan- & stan- & stan- & stan- \\
\hline dard & dard & dard & dard & dard & dard & dard & dard & dard & dard \\
\hline $\begin{array}{l}\text { devia- } \\
\text { tion }\end{array}$ & $\begin{array}{l}\text { devia- } \\
\text { tion }\end{array}$ & $\begin{array}{l}\text { devia- } \\
\text { tion }\end{array}$ & $\begin{array}{l}\text { devia- } \\
\text { tion }\end{array}$ & $\begin{array}{l}\text { devia- } \\
\text { tion }\end{array}$ & $\begin{array}{l}\text { devia- } \\
\text { tion }\end{array}$ & $\begin{array}{l}\text { devia- } \\
\text { tion }\end{array}$ & $\begin{array}{l}\text { devia- } \\
\text { tion }\end{array}$ & $\begin{array}{l}\text { devia- } \\
\text { tion }\end{array}$ & $\begin{array}{l}\text { devia- } \\
\text { tion }\end{array}$ \\
\hline $\mathrm{TP}-$ & $\mathrm{TP}-$ & $\mathrm{TP}-$ & $\mathrm{TP}-$ & $\mathrm{TP}-$ & $\mathrm{TP}-$ & $\mathrm{TP}-$ & $\mathrm{TP}-$ & $\mathrm{TP}-$ & $\mathrm{TP}-$ \\
\hline true & true & true & true & true & true & true & true & true & true \\
\hline posi- & posi- & posi- & posi- & posi- & posi- & posi- & posi- & posi- & posi- \\
\hline tive & tive & tive & tive & tive & tive & tive & tive & tive & tive \\
\hline $\mathrm{TN}-$ & $\mathrm{TN}-$ & $\mathrm{TN}-$ & $\mathrm{TN}-$ & $\mathrm{TN}_{1 \overline{6}}$ & $\mathrm{TN}-$ & $\mathrm{TN}-$ & $\mathrm{TN}-$ & $\mathrm{TN}-$ & $\mathrm{TN}-$ \\
\hline true & true & true & true & true & true & true & true & true & true \\
\hline nega- & nega- & nega- & nega- & nega- & nega- & nega- & nega- & nega- & nega- \\
\hline tive FP & tive FP & tive $\mathrm{FP}$ & tive $\mathrm{FP}$ & tive FP & tive FP & tive FP & tive FP & tive FP & tive FP \\
\hline - false & - false & - false & - false & - false & - false & - false & - false & - false & - false \\
\hline $\begin{array}{l}\text { posi- } \\
\text { tive }\end{array}$ & $\begin{array}{l}\text { posi- } \\
\text { tive }\end{array}$ & $\begin{array}{l}\text { posi- } \\
\text { tive }\end{array}$ & $\begin{array}{l}\text { posi- } \\
\text { tive }\end{array}$ & $\begin{array}{l}\text { posi- } \\
\text { tive }\end{array}$ & $\begin{array}{l}\text { posi- } \\
\text { tive }\end{array}$ & $\begin{array}{l}\text { posi- } \\
\text { tive }\end{array}$ & $\begin{array}{l}\text { posi- } \\
\text { tive }\end{array}$ & $\begin{array}{l}\text { posi- } \\
\text { tive }\end{array}$ & $\begin{array}{l}\text { posi- } \\
\text { tive }\end{array}$ \\
\hline
\end{tabular}


Table 4 : Summary of characteristics of randomised controlled trials and observational studies using CoMiSS $^{\mathrm{TM}}$ as an outcome measure for symptom evolution.

\section{Study}

Dupont, 2016

Rossetti, 2019

Vandenplas, 2013

Vandenplas, 2014

Vandenplas, 2014

CMPA - cow's milk protein allergy eCH - extensive casein hydrolysate eHCF - extensively hydrolysed casein-based formule

\section{Figure legends}

Figure 1. Selection process for study inclusion.

Figure 2. CoMiSS ${ }^{\mathrm{TM}}$ awareness tool for CMPA. Adapted from Nestlé Health Science form.

Figure 3. CMPA questionnaire created by Gibbons et al.

Figure 4. Summary of methodological quality across studies based on QUADAS-2.

Figure 5. Forest plots for test accuracy of CoMiSS ${ }^{\mathrm{TM}}$ tool and CMPA questionnaire.

\section{Supplementary files}

Supplementary File 1: Search strategies

Supplementary File 2: Data extraction forms

Supplementary File 3: Methodological quality of DTA studies

\section{Hosted file}

Figure 1.docx available at https://authorea.com/users/350378/articles/475241-a-comprehensiveevaluation-of-symptom-scores-designed-to-inform-the-triage-and-diagnosis-of-cow-s-milkprotein-allergy-in-children-a-systematic-review-of-the-research-evidence

\section{Hosted file}

Figure 2.docx available at https://authorea.com/users/350378/articles/475241-a-comprehensiveevaluation-of-symptom-scores-designed-to-inform-the-triage-and-diagnosis-of-cow-s-milkprotein-allergy-in-children-a-systematic-review-of-the-research-evidence

\section{Hosted file}

Figure 3.docx available at https://authorea.com/users/350378/articles/475241-a-comprehensiveevaluation-of-symptom-scores-designed-to-inform-the-triage-and-diagnosis-of-cow-s-milkprotein-allergy-in-children-a-systematic-review-of-the-research-evidence

\section{Hosted file}

Figure 4.docx available at https://authorea.com/users/350378/articles/475241-a-comprehensiveevaluation-of-symptom-scores-designed-to-inform-the-triage-and-diagnosis-of-cow-s-milkprotein-allergy-in-children-a-systematic-review-of-the-research-evidence

\section{Hosted file}


Figure 5.docx available at https://authorea.com/users/350378/articles/475241-a-comprehensiveevaluation-of-symptom-scores-designed-to-inform-the-triage-and-diagnosis-of-cow-s-milkprotein-allergy-in-children-a-systematic-review-of-the-research-evidence 